\title{
Depletion of the Land Resources and Its Effect on the Environment
}

\author{
M. Abou Zahr Diaz, M. A. Alawiyeh, and M. Ghaboura ${ }^{(\bowtie)}$ \\ Department of Mineral Developing and Oil \& Gas Engineering, \\ Engineering Academy, RUDN University, Moscow, Russia \\ mostafa_ghab@live.com
}

\begin{abstract}
Resources depletion refers to the situation where the consumption of natural resources is faster than it can be replenished. In order to achieve economic growth, developing countries are abusing their lands on the grounds of economic interests. Population Explosion is acting as a catalyst for resources depletion. It seems evident that developing countries pursuing rapid economic growth disregard environmental concerns. The natural resources contribute at large to the economic development of a nation. Consumption pattern if not addressed will lead to irreversible climate change and declined economic growth, as a result of increased social, economic, and environmental costs and decreased productivity. Resource utilization has always been part of human history; however, the acceleration of economic growth activities together with the pursuit of an urgent economic development is the core cause of resources overexploitation. Consumption pattern will lead to irreversible climate change and declined economic growth.
\end{abstract}

Keywords: Resources · Economics · Population - Utilization · Depletion of the soil

\section{Introduction}

In addition to the problems of each civilization, humanity is faced with the urgent need to solve planetary problems. At the end of XX century, the first terrible signs of the deterioration of the quality of the biosphere had already appeared as a result of the development of man-made civilization and the installation to conquer nature started.

Smog over large cities, deforestation and the onset of deserts, depletion of the soil and basins of many rivers, a decrease in the number of fish and wild animals - all this worried people at the beginning of the twentieth century.

\section{Methods and Approaches}

A no less formidable problem is the ecological catastrophe approaching the planet. At present, mankind produces organic waste in an amount of two thousand times more than the waste volumes of the rest of the biosphere. Obviously, the violation of this equilibrium caused a whole complex of complex problems. Man, unlike all living things, is not strictly bound by the environmentally friendly conditions of his being, in 
a certain sense he was always going against nature, not adapting to it, but changing it in accordance with its needs (Satterthwaite 2009).

\section{Results and Discussion}

The demographic problem has become global long ago. In 1987, the five billionth inhabitant of the planet was born, and the growth rate is now such that every second the number of people on Earth is increased by three people (Anderson 2012). According to the figurative expression of scientists, the Earth is now "biting man" and it is quite natural to expect a demographic collapse in the near future, that is, a sufficiently sharp decline in population.

It can be caused by global hunger, depletion of mineral resources and soil, poor drinking water, thermal overheating of the surface, etc.

\section{Conclusions}

The current generation cannot help thinking about future children and grandchildren, who are to continue to carry the baton of history. Unfortunately, our civilization largely lives at the expense of the future, exhausting irreplaceable resources (oil, gas), polluting water, air and soil with its imperfect technologies, preserving many archaic social structures, sowing seeds of national and religious hatred that will sprout another century.

Based on the above, it can be concluded that only the efforts of the entire world community can prevent an environmental catastrophe that threatens all life on Earth.

\section{References}

Anderson R (2012) Resource depletion: opportunity or looming catastrophe? https://www.bbc. com/news/business- 16391040

Satterthwaite D (2009) The implications of population growth and urbanization for climate change. Environ Urbanization 21(2):545-567

Open Access This chapter is licensed under the terms of the Creative Commons Attribution 4.0 International License (http://creativecommons.org/licenses/by/4.0/), which permits use, sharing, adaptation, distribution and reproduction in any medium or format, as long as you give appropriate credit to the original author(s) and the source, provide a link to the Creative Commons license and indicate if changes were made.

The images or other third party material in this chapter are included in the chapter's Creative Commons license, unless indicated otherwise in a credit line to the material. If material is not included in the chapter's Creative Commons license and your intended use is not permitted by statutory regulation or exceeds the permitted use, you will need to obtain permission directly from the copyright holder.

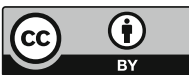

